Revista Perspectivas Online: Humanas \& Sociais Aplicadas Anais do V Seminário P\&D PROVIC/PIBIC

II Encontro de Iniciação Científica CNPq

V. $10, n^{\circ} 28$, Suplemento, 2020

\title{
Subjetividade e produção midiática sobre drogadição
}

\author{
Raphael Fonseca Braga de Melo ${ }^{I}$,Rebecca Rodrigues Cedro de Brito ${ }^{I}$,Érica Henrique Ribeiro- \\ Andrade ${ }^{2}$

\begin{abstract}
${ }^{1}$ Aluno de iniciação cientifica do PROVIC - Institutos Superiores de Ensino do CENSA - ISECENSA - Laboratório de estudos sobre drogadição Rua Salvador Correa, 139, Centro, Campos dos Goytacazes, RJ, CEP: 28035-310, Brasil; ${ }^{2}$ Coordenadora da Linha de Estudos sobre Drogadição (LED) filiada ao Núcleo de Estudos sobre Processos de Estigmatização (NEPE) Institutos Superiores de Ensino do CENSA - ISECENSA Laboratório de estudos sobre drogadição - Rua Salvador Correa, 139, Centro, Campos dos Goytacazes, RJ, CEP: 28035-310, Brasil;
\end{abstract}

As mídias e suas formas de representação da realidade têm importante papel na construção social. No que tange a drogadição, conhecida mais frequentemente como dependência química, a sociedade vem desenvolvendo formas de compreensão desta realidade a partir do que se veicula enquanto informações e notícias sobre ela. É neste sentido que se faz necessário que as ciências humanas e sociais estabeleçam uma crítica acerca da representação midiática sobre os mais variados estados de adoecimentos psicossociais, uma vez que é neste contexto que os profissionais atuarão. Esta pesquisa objetiva identificar as matérias sobre drogadição publicadas numa revista de grande circulação nacional, a saber a Revista VEJA. Além disso, comparar o conteúdo destas publicações com o que é veiculado por outras fontes de informações também de grande circulação, qual seja, o Jornal Folha de São Paulo, e o site Scielo Brasil, mais acessado pelas comunidades científicas. Realizar-se-á um primeiro levantamento teórico a partir de autores que apresentam o tema das Produções Midiáticas e as representações sociais, mais especificamente o universo das três tipologias investigadas nesta pesquisa: revista, jornal e plataforma científica. Este levantamento teórico também incluirá uma conceituação geral sobre drogadição. Após a pesquisa bibliográfica, a coleta de dados terá como fonte de informações as publicações da Revista VEJA (versão online), a plataforma virtual Scielo Brasil e o Jornal Folha de São Paulo (versão online). Para estas três fontes utilizar-se-á o critério temporal de cinco anos a contar de janeiro de 2016 a dezembro de 2020. Aplicar-se-á os critérios gerais para Análise de Conteúdo (Bardin, 2011) que implica três distintas fases: pré-análise, exploração do material e interpretação dos dados. Infere-se que ao final da pesquisa seja possível perceber peculiaridades inicialmente ofuscadas e desconexas. Acredita-se que será possível identificar tendências ideológicas envoltas na forma de publicação acerca dos fenômenos adictivos. Como resultado espera-se ainda, obter dados relevantes o suficiente que indiquem a necessidade de novas pesquisas e novas modalidades de levantamento de dados sobre a temática.

Palavras-chave: Adicção. Mídia. Psicologia.

Instituição de Fomento: ISECENSA. 